\title{
Imaginários urbanos, coletivos sociotécnicos e vigilância cívica: a vida social em rede e os novos espaços da moralidade ${ }^{1}$
}

José Pedro Arruda

\author{
Doutorado em Sociologia pela Universidade de \\ Coimbra.
}

http://dx.doi.org/10.1590/1981-5344/3163

Desenvolve-se aqui uma reflexão em torno das ideias de ciberativismo e de vigilância cívica através das denominadas "redes sociais". Parte-se de uma análise comparativa entre o funcionamento de duas dessas redes, o Facebook e o 4chan, salientando-se como as plataformas tecnológicas condicionam e modelam o tipo de interações que aí ocorrem. Os coletivos sociotécnicos que interagem através dessas redes são dinâmicos e performativos, pelo que, no processo comunicacional que aí decorre, há vários conceitos que vão sendo redefinidos e reconstruídos. Assim, discutem-se também as noções de público e privado, pessoal e político, ativismo e resistência, verdade e pós-verdade. Analisam-se ainda diferentes estratégias de ação possíveis nesses novos espaços, nomeadamente o anonimato ou $a$ personalização, que representam formas diferentes de lidar com a vigilância cívica, abrindo também lugar ao debate entre a liberdade de expressão e o politicamente correto.

Palavras-chave: Facebook. 4chan. Vigilância cívica. Ativismo. Resistência.

\section{Urban Imaginaries, Sociotechnical Collectives and Civic Vigilance: the}

\footnotetext{
${ }^{1}$ Este artigo foi elaborado no âmbito do projeto de investigação intitulado "Policiamento e imaginários urbanos: novos formatos de segurança em Cidades do Sul" (Ref.a: FAPESP/19989/2014), o qual é financiado pela Fundação para a Ciência e a Tecnologia (FCT) e pelo Fundo de Amparo à Pesquisa do Estado de São Paulo (FAPESP), decorrendo em simultâneo em Portugal e no Brasil.
} 


\title{
networked social life and the new spaces of morality
}

\begin{abstract}
This article presents a reflection on the ideas of cyberactivism and civic surveillance on the so-called social networks. From a comparative analysis of the functioning of Facebook and 4chan, the article shows how these technological platforms limit and model interaction between sociotechnical collectives, whose dynamic and performative nature helps to redefine and rebuild various concepts. For this reason, the notions of public and private, personal and political, activism and resistance, truth and post-truth are discussed herein. Various possible action strategies in these new spaces are also discussed, namely anonymity and personalization, which represent different forms of dealing with civic surveillance, opening the debate between freedom of speech and political correctness.
\end{abstract}

Keywords: Facebook. 4chan. Civic surveillance. Activism. Resistance.

Recebido em 11.05.2017 Aceito em 18.06.2018

\section{Introdução}

Quem, como eu, nasce e cresce numa localidade pequena, pósindustrial e com reminiscências de uma mentalidade rural, marcada por forte influência religiosa, acaba por apreender, pela experiência, várias das dimensões do conceito de "comunidade". Em meios sociais com estas características, com limitações e fronteiras restritas, o controlo dos comportamentos individuais dentro daquilo que é moralmente aceitável estabelece-se de forma compulsiva em diferentes espaços de socialização: família, escola, catequese, ou mesmo em brincadeiras de rua em que a vizinha já de certa idade se põe à janela a gritar "vão fazer isso para outro lado, canalha brava!". Desde cedo percebemos que há regras a seguir para pertencermos ali, para sermos parte do todo, do grupo, da comunidade que nos rodeia. No início da vida adulta, fui finalmente viver para uma cidade. Conheci várias e vivi em algumas. E fui aprendendo que nos mundos urbanos, apesar de nem tudo ser diferente, há variações subtis que alteram substancialmente a forma de as pessoas se relacionarem umas com as outras. E essas diferenças têm vindo a acentuar-se, como defendo neste artigo, pela presença cada vez mais ostensiva de elementos tecnológicos no processo de interacção social. Não 
significa isto que nos meios rurais as pessoas não utilizem as mesmas tecnologias; simplesmente parece-me que o que estas fazem é promover e acentuar um tipo de socialização tipicamente urbano.

Desde que vim viver para uma cidade da dimensão de Lisboa, houve um contexto que se começou a afigurar-me como verdadeiramente paradigmático do modo de vida urbano: as deslocações quotidianas no metro. O metro é a verdadeira montra hiper-real da vida numa cidade, onde milhares de pessoas que se cruzam diariamente, sem se verem, embora partilhando o mesmo espaço físico. Quem não está habituado a esse tipo de impessoalidade não deixa de estranhá-la, pelo menos numa fase inicial. Progressivamente, isso vai-se assimilando, da mesma forma que se assimilam certas regras, que não precisam de ser ditas nem de estar escritas em algum boletim informativo. Por exemplo, rapidamente se aprende que não é suposto falar-se com os desconhecidos que se sentam à nossa frente ou ao nosso lado. Mas, mais que isso, percebe-se quase instintivamente que é deselegante ou mesmo rude ficar a fitar alguém que partilha connosco a carruagem. Trocas de olhares, se as houver, devem ser fugazes e fortuitas, sem qualquer intenção comunicativa associada. Há um respeito latente pela privacidade alheia, mesmo tratando-se de um espaço teoricamente "público".

Outro aspeto que se evidencia na utilização contemporânea destes espaços (e de vários outros, sendo este aqui usado apenas como paradigma), é a ação efetiva de vários elementos não-humanos, que contribuem para o reforço deste tipo de comportamento. Falo sobretudo das tecnologias de comunicação de uso pessoal, particularmente dos smartphones. De facto, eles tornaram-se companheiros inseparáveis do dia-a-dia das pessoas. No metro, isso torna-se ostensivamente percetível, tanto pela quantidade de utilizadores como pelo tipo de função que estes dispositivos executam. Eles atuam como "mecanismos de isolamento individual", favorecendo um fechamento da pessoa no seu próprio espaço privado. Claro que existem outros destes mecanismos; ainda há quem prefira utilizar os livros para o mesmo propósito, por exemplo. Mas esses serão quase "os resistentes" e encontram-se em clara minoria. É que os smartphones oferecem, sem dúvida, um mecanismo de isolamento muito mais eficaz: além do isolamento visual, provocado pelo foco no dispositivo, permite ainda o isolamento auditivo, pelo uso de auriculares, assim como um deslocamento social para outros espaços, que será o principal aspeto a ser abordado neste artigo.

Em suma, o que o uso destas tecnologias permite é a segregação do espaço público em inúmeros microespaços privados, que podem assim ser reforçados e materializados pela ação dos não-humanos. Esta justaposição ou coexistência de espaços públicos e privados não acontece exclusivamente pela ação das novas tecnologias de comunicação. Já anteriormente foi sugerido que a fusão entre os espaços públicos e privados é uma das características do novo paradigma comunicacional em que vivemos, mesmo tratando-se de meios mais cristalizados, como a televisão (Arruda, 2016). No entanto, o que é particularmente desafiador 
no tipo de comunicação mediada por estas novas tecnologias de uso pessoal é a possibilidade de integração em novos espaços de socialização, diferentes daqueles em que os indivíduos fisicamente interagem. Estes novos espaços, comummente designados por "redes sociais", desenvolvem-se no mundo cibernético, materializam-se através das tecnologias e são estruturados pela ação dos diversos atores envolvidos em vastos coletivos sociotécnicos. Neles redefinem-se conceitos como público e privado, entre vários outros binómios que serão aqui abordados. Para melhor delimitar a discussão, irei focar-me apenas em duas dessas denominadas redes sociais, que a vários níveis são quase o oposto existencial uma da outra: o Facebook e o 4chan.

\section{Desconstruindo as "redes sociais" e o "isolamento urbano"}

É importante referir que a reflexão que aqui se desenvolve surge no âmbito de um projeto de investigação intitulado "Policiamento e imaginários urbanos: novos formatos de segurança em cidades ao sul". Um dos propósitos deste projeto é explorar a ideia de um certo "policiamento cívico", um tipo de policiamento e vigilância protagonizado não pelas forças de segurança oficiais (públicas ou privadas), mas que parte da própria sociedade civil e de grupos de cidadãos empenhados em causas sociais, através de um controlo de práticas públicas ou que afetem a vida comunitária. Estas novas práticas de controlo social desenvolvemse sobretudo no ciberespaço e assumem muitas vezes uma forma que pode ser entendida genericamente como "ciberativismo" ou mesmo "hacktivismo", conceito que desafia algumas fronteiras da legalidade e da ética, quando não as coloca mesmo em confronto. Um exemplo mediático e ilustrativo deste tipo de atividades é o grupo conhecido como Anonymous, que acabou por ser o ponto de partida para esta investigação. Porém, as diversas facetas e os múltiplos modus operandi deste coletivo (o próprio conceito de "grupo" pode não ser totalmente adequado neste caso), pormenorizadamente descritos na obra de Gabriella Coleman (2016), desde cedo começaram a levantar questões problemáticas, como a própria noção de "ativismo" ou de "controlo social".

A necessidade de redefinir ou pelo menos questionar esses conceitos acabou por conduzir a uma reflexão mais ampla sobre o próprio funcionamento das "redes sociais" enquanto mecanismos de controlo e de vigilância cívica. No Facebook proliferam páginas que se dedicam inteiramente a denunciar e divulgar práticas moralmente questionáveis ou politicamente incorretas, sobretudo por parte de governantes, instituições públicas, figuras públicas, forças de segurança ou dos media. Uma declaração polémica ou uma notícia chocante podem rapidamente tornarse virais, sendo amplamente difundidas por um vasto número de coletivos. Esta atividade de partilha e denúncia pode considerar-se uma forma primária e mais ou menos 'suave' de ciberativismo. Mas esta prática não se restringe a grupos ou associações assumidamente 
"ativistas"; pode ser também levada a cabo por utilizadores 'individuais', em nome próprio. No entanto, há que ter em conta que nada no Facebook pode ser considerado exclusivamente individual: pela sua própria lógica de funcionamento, todas as publicações se tornam coletivas.

Já no 4chan, por sua vez, a ideia de agir "em nome próprio" perde todo o sentido. Isso acontece sobretudo pela lógica da preservação do anonimato, que é uma das componentes características desta plataforma. O 4chan não tem o propósito de permitir uma reconfiguração pública do self, mas antes o de ser um espaço de partilha totalmente livre dos mais diversos conteúdos, desde elementos da pop culture até aos produtos mais bizarros da imaginação humana. Voltarei de novo a esta análise comparativa entre as duas redes sociais aqui discutidas. Para já, o importante a reter é que o conceito genérico de "redes sociais" não nos permite ver as especificidades e particularidades de cada plataforma. 0 tipo de ação e de interação que cada uma delas permite apresenta condicionalismos próprios, tanto pelas características técnicas e formais de cada site, como pelos efeitos que essa atuação pode ter na vida social dos utilizadores. É fundamental ter em conta que nem todas as "redes sociais" funcionam da mesma maneira nem podem ser usadas para os mesmos propósitos, embora tenham entre si alguns pontos de contacto e partilha de elementos comuns.

Por outro lado, é preciso também esclarecer aquilo que foi dito na parte introdutória deste texto, sobre a socialização urbana. Se é plausível que o metro funcione como paradigma da vida urbana, também é necessário questionar se esse aparente isolamento individual é realmente efetivo. Na verdade, seria demasiado ingénuo e até preconceituoso afirmar taxativamente que as pessoas nas cidades não socializam umas com as outras. Pelo contrário, quando estão imersas nas suas redes cibernéticas, elas estão de facto a conectar-se umas com as outras, a socializar e a formar coletivos. O que é tipicamente urbano neste processo não é o isolamento individual, mas sim a liberdade individual para escolher em que coletivos cada pessoa se quer integrar. Ao contrários das "comunidades" rurais em que cada indivíduo é impelido a integrar-se naquele todo que lhe é apresentado, no mundo urbano as pessoas têm muito maior liberdade para escolherem que coletivos pretendem ou não integrar. $E$ isso assemelha-se, em grande medida, àquilo que acontece nas redes sociotécnicas do espaço 'virtual'. Será por isso importante tentar perceber o funcionamento e as dinâmicas destas plataformas e o tipo de interação que as mesmas possibilitam.

\section{Breve análise do funcionamento do Facebook e do 4chan}

O Facebook constitui um espaço onde as noções de público e privado se tornam mais fluidas e justapostas. Se é certo que aquilo que se publica no Facebook, como o próprio verbo indica, é tornado público, este "público" é restrito e resulta decisões individuais de cada usuário. Aquilo 
que se publica é partilhado com uma rede semiprivada, já que cada pessoa tem a possibilidade de adicionar ao seu grupo de "amigos" apenas quem desejar. Além disso, em cada "postagem", o utilizador pode seleccionar o grau de privacidade da sua publicação: pode estar disponível para qualquer pessoa, apenas para os amigos ou só mesmo para alguém em particular. Deste modo, o grau de exposição pública a que cada utilizador se sujeita é em certa medida definido pelas suas opções privadas. Porém, existe um risco permanente de que cada uma dessas publicações semiprivadas transcenda os limites impostos pelo próprio autor. Basta para isso que alguém da sua rede decida partilhar essa postagem na sua própria página, dando assim acesso à mesma a toda a sua rede. Este processo pode repetir-se múltiplas vezes, sendo dessa forma que algumas publicações acabam por tornar-se virais e amplamente difundidas.

Claro que esse risco de sobreexposição pública de uma postagem inicialmente pensada para um grupo mais ou menos restrito ocorre sobretudo com pessoas que são já figuras públicas. Por exemplo, ainda recentemente, o fadista português João Braga, figura pública mas já um pouco afastado do apogeu da fama, foi profusamente comentado, difundido e criticado por algumas declarações de teor racista e homofóbico. Os comentários foram inicialmente feitos na sua página pessoal, seguida apenas por pessoas autorizadas por ele a tal. No entanto, rapidamente essa postagem foi difundida por um grande número de coletivos distintos e comentado por imensas pessoas que nunca visitaram sequer o espaço do músico. Este mecanismo, o da partilha de publicações de outrem, é uma das formas mas eficazes de tornar aquilo que é semiprivado em discussões largamente públicas. À partida, pessoas "anónimas" ou desconhecidas do público em geral terão muito menor grau de risco em ver algo parecido a acontecer-lhe. Mas, na prática, ninguém está verdadeiramente imune a essa possibilidade.

Além do mecanismo da partilha, o Facebook dispõe de outros mecanismos que favorecem igualmente este caráter potencialmente expansivo das redes sociais de cada utilizador. Um deles é o comentário. Através do comentário, os outros membros da rede podem intervir naquela postagem, concordando, discordando, reforçando ou contradizendo. A possibilidade do comentário faz com que o processo comunicacional, mesmo dentro de uma rede 'privada', deixe de assemelhar-se a um todo harmonioso e amigável e possa tornar-se, em qualquer momento, num jogo agonístico onde há controvérsias e disputas. Em casos extremos, esses desaguisados podem conduzir mesmo a um processo de "dasamigamento" de alguém. Nem toda a gente aceita da melhor forma o difundir de ideias diferentes das suas na sua própria página, assumida então quase como "o seu espaço privado", onde cada usuário pode estabelecer as suas próprias regras e limites para o que é tolerável ou aceitável. Esta é mais uma evidência de que, no Facebook, as definições de público e privado não são totalmente claras e têm de ser performatizadas e negociadas pelo uso destes mecanismos. 
Simultaneamente, o comentário tem o potencial de trazer 'elementos estranhos' para a discussão. Dependendo das opções de privacidade de quem faz a publicação, a mesma pode ser acedida por elementos que não fazem parte da sua rede, mas da rede de quem comenta, atingido assim públicos 'desconhecidos'. O mesmo acontece com o mecanismo do "like". Este será provavelmente o mecanismo mais emblemático da comunicação através do Facebook. O like é uma forma rápida de dizer, sem palavras, "eu vi o que publicaste e gostei" ou de estabelecer concordância, reconhecimento ou valorização. Funciona ainda como um reforço da conexão entre as pessoas envolvidas. É um cumprimento, mas também uma dádiva, no sentido maussiano de uma ação que impele a uma retribuição futura. É uma forma de dizer também "eu reparei em $\mathrm{ti}$, espero que repares em mim". Independentemente da 'força' dessa conexão poder ser discutida, é sempre uma ação que visa fortalecer ou reforçar a ligação entre alguns dos elementos da rede. Nos últimos anos, o like ganhou novas "emoções", que podem dar uma ideia mais precisa do tipo de reação que a publicação suscita, nomeadamente tristeza, gargalhada, fúria, espanto ou adoração. Isso amplia o potencial comunicativo do like, mas não altera substancialmente o seu propósito de reforço da conexão.

Em suma, todos estes mecanismos (partilha, comentário e like) favorecem o potencial público do Facebook, até níveis que podem efetivamente escapar em larga medida ao controlo dos utilizadores. No entanto, há formas de tentar manter algum nível de privacidade no espaço pessoal de cada um. Isso dependerá sempre das ações de cada usuário na gestão das suas redes, definições de uso e mesmo práticas de interação social. Em certa medida, cada um tem de negociar e redefinir, na prática, a sua "política de privacidade". Há também um espaço marcadamente mais privado dentro do próprio Facebook. São os espaços de conversação individual, em que duas ou mais pessoas podem falar exclusivamente entre si. Estes são lugares de convívio privado, em que as pessoas interagem diretamente umas com as outras, por intermédio das tecnologias e dos códigos próprios deste tipo de conversação (siglas, smiles, texto escrito, imagens, vídeos, etc.). É seguramente o espaço mais privado desta rede pública, seguida de perto pelos "grupos privados", cujas publicações ficam apenas acessíveis aos membros, que têm de ser aprovados por quem regular o grupo em questão.

Este tipo de privacidade (conversação individual ou restrita) não existe no 4chan. Na verdade, nesta plataforma todas as postagens são públicas e qualquer pessoa pode aceder-lhes, uma vez que não é necessário alguém registar-se nesta rede social para ter acesso aos seus conteúdos e/ ou participar ativamente na mesma. No entanto, existe um mecanismo de preservação da privacidade que é, possivelmente, mais eficaz que qualquer um dos existentes no Facebook: o anonimato dos utilizadores. No 4chan, todos os utilizadores são identificados como "anonymous". E, tal como documenta Coleman (cf. 2016), este foi o local de nascimento do grupo hacktivista Anonymous, cujo nome deriva 
precisamente desta particularidade. Ou seja, a estratégia de manutenção da privacidade, no 4chan, não passa pela tentativa de restrição do acesso a certos conteúdos por parte de outros utilizadores, mas sim pela ocultação das identidades dos próprios utilizadores. Esta diferença revelase profundamente significativa e transforma radicalmente tanto a dinâmica de funcionamento como o próprio teor dos conteúdos populares nas duas diferentes plataformas.

O 4chan nasceu em 2003 e rapidamente se tornou uma plataforma popular entre algumas comunidades "geek" da internet, nomeadamente entre amantes de séries de "anime" e "manga" japonesas. Porém, os seus conteúdos foram-se expandindo com o tempo e atualmente este site oferece uma imensa variedade de temas e áreas de interesse, que vão desde a cultura pop a videojogos, atividades de lazer, política, pornografia, tecnologia ou culinária. Os temas são tão variados quanto os interesses das pessoas que utilizem a página, pois mesmo os recémchegados podem começar imediatamente a publicar conteúdos. Talvez a secção mais paradigmática do 4chan seja a denominada secção /b/, dedicada a conteúdos "random" (variados). Esta é uma das secções mais populares e mais ativas de todo o fórum, e revela na perfeição a diversidade temática quase caótica que o 4chan pode atingir. É também um espaço caracterizado essencialmente pela liberdade (quase) total de expressão. Nesta secção, são permitidos certos conteúdos que seriam banidos pelos moderadores (também eles anónimos) em qualquer outra parte do site, incluindo publicações de caráter racista, grotesco ou moralmente condenável pela grande maioria das convenções sociais.

A secção /b/ é então o lugar onde a ideia de base do 4chan, que é a liberdade de expressão, atinge o seu auge. A única regra que se lhe aplica é a regra genérica do site de não publicar nada que viole a lei local ou a lei nacional dos Estados Unidos da América - o 4chan é originalmente americano e a língua utilizada nos fóruns e subfóruns é quase exclusivamente o inglês, embora haja utilizadores de diversos países do mundo. O desprezo pelo politicamente correto é uma das características mais proeminentes do /b/, onde o principal objetivo parece ser o de chocar o máximo possível, ou então simplesmente fazer rir com o achincalhamento de alguém ou de algum grupo. É por isso o palco ideal para o desenvolvimento de uma figura muito conhecida por toda a internet: a do "troll". O troll é alguém que utiliza as redes sociais cibernéticas para sistematicamente desestabilizar discussões, provocar pessoas de todas as formas possíveis até à exaustão, conduzindo à impossibilidade absoluta de manter uma troca racional de argumentações ou debate de pontos de vista divergentes. O anonimato é, por norma, uma das premissas para um troll. Ele não tem identidade nem pretende ser reconhecido; pelo contrário, é esse anonimato que o liberta para dizer tudo o que quiser.

Há um outro conceito que é fundamental para compreender as intervenções públicas de um troll: o de "lulz". Lulz é uma corruptela do "lol", que significa "Laugh Out Loud" (rir em voz alta) em linguagem 
comum da internet. O lulz é uma atitude de escárnio em relação a alguém ou alguma coisa, pelo simples gozo que isso mesmo encerra. Na sua essência, não tem uma finalidade política nem sequer de crítica social. É algo que se faz apenas porque diverte, embora a maioria das vítimas sejam geralmente alguém de quem não se gosta. No entanto, como também revela Coleman (2016) o lulz acabou por desencadear a primeira intervenção pública e "política" dos Anonymous enquanto grupo. Tudo começou com a partilha, no 4chan, de um vídeo do ator Tom Cruise em que este revelava alguns dos segredos da Igreja da Cientologia. Caindo no 4chan, depressa o vídeo se tornou viral, suscitando sobretudo reações de gozo e troça. A Igreja da Cientologia não gostou e tentou impedir a difusão do vídeo, avançando mesmo com um processo jurídico contra o 4chan. Os Anonymous, até ali sem identidade coletiva, sentiram isso como um ataque intolerável à sua liberdade de expressão e uniram-se em torno de um objetivo comum: declarar guerra à Cientologia!

\section{Ativismo vs Resistência}

As formas de combate que os Anonymous utilizaram inicialmente contra a Igreja da Cientologia, em larga medida, dificilmente podem ser consideradas "políticas", pelo menos da forma como habitualmente se entende a política. O próprio 'toque a reunir', difundido pelo 4chan, apelava a uma nova forma de "guerra", a um novo conceito de intervenção política: "quando forem vitoriosos, os chan unir-se-ão num novo capítulo da existência dos Anonymous e de extrema insanidade, e teremos iniciado a nossa conquista do mundo. Se pudermos destruir a Cientologia, podemos destruir tudo o que quisermos! O mundo será o nosso objeto de divertimento." (in Coleman, 2016: 61). Este excerto da mensagem revela a intenção de lulz como fonte de motivação e o propósito declarado de "trollar" a Igreja da Cientologia. Seguiram-se diversas ações que se enquadravam neste projeto: os sites da Cientologia foram pirateados, com ataques negação de serviço (também conhecidos como DDoS, acrónimo em inglês para Distributed Denial of Service), congestionaram as suas linhas telefónicas com chamadas falsas e brincadeiras infantis, enviaram faxes de folhas totalmente negras ou com imagens apenas ridículas, como a digitalização do rabo de alguém ou até encomendavam pizzas para as suas instalações. Durante vários dias, este tipo de ataques repetiu-se com grande intensidade.

No entanto, vários dos anonymous não estavam totalmente satisfeitos com este tipo de intervenção e pretendiam ir mais longe. Após algumas controvérsias, um vídeo de um dos membros acabou por conseguir mobilizar grande parte do coletivo para uma intervenção nas ruas, pública e que desse maior visibilidade à sua luta. Sugeriu-se que os manifestantes fossem todos mascarados, para evitar perseguições e represálias por parte da Igreja da Cientologia e dos seus advogados. Daí surgiu a ideia de utilizarem as máscaras do Guy Fawkes, popularizadas pelo filme $V$ for Vendetta, que acabariam por se tornar icónicas do 
movimento Anonymous. A manifestação aconteceu semanas depois, simultaneamente em várias cidades dos Estados Unidos da América e teve uma adesão que superou em muito as expectativas dos próprios organizadores. Foi quase o despertar de uma consciência coletiva: num momento, e de forma totalmente surpreendente, os Anonymous perceberam que tinham poder de mobilização, que juntos poderiam ter uma força social a ter em conta pois, de repente, estavam milhares de pessoas na rua, espalhadas por vários estados, e toda a atenção dos media caía sobre eles. O anonimato individual dos membros tinha dado lugar a uma visibilidade coletiva com uma dimensão que eles próprios não previam. Os Anonymous tinham-se tornado legião.

A história que se seguiu é complexa e não será aqui explorada. Importa dizer que esse foi o ponto de partida para outras intervenções de grande relevo social e mediático, nomeadamente anos depois quando ocorreu a Primavera Árabe. Os Anonymous solidarizaram-se com os movimentos de contestação política que estavam a ocorrer em vários países do Norte de África e decidiram tomar o partido dos revoltosos, contribuindo com os diversos meios que estavam à sua disposição. O mais importante a reter é que foi a partir do lulz e do trolling, atividades propícias a indivíduos anónimos que se escondem por detrás de um monitor, que surgiu um movimento que pretendia intervir ativamente na vida social e política, de uma forma transnacional, pública, visível enquanto um todo e eticamente empenhada. Estas transformações não foram lineares nem pacíficas e muito menos consensuais entre os Anonymous e outros utilizadores do 4chan. Houve avanços e recuos, cisões e discórdias quanto aos tipos de intervenções a realizar e mesmo sobre a adesão ou não a intervenções de cariz ético e socialmente comprometido. Mas era inegável que um grupo de pessoas anónimas tinha conseguido criar algo maior que elas próprias, um coletivo com uma imagem, uma ideia, um poder ameaçador para os governantes e um vasto leque de formas de ação conjunta.

Em Everyday Forms of Resistance, James Scott (1989) salienta que as principais estratégias de resistência quotidiana de pessoas desprovidas de poder e submetidas a várias formas de poder coercivo passam sobretudo pelo anonimato e pela discrição. Táticas como a caça furtiva, a fuga aos impostos por ocultação das quantidades reais de produção ou a deserção são utilizadas em sigilo por quem tem de sobreviver dentro de um sistema opressivo. Elas são assim, por norma, privadas, anónimas e silenciosas, ao contrário do tipo de resistência política que geralmente é reconhecida como tal: a dos movimentos sociais, partidários ou sindicais, que fazem da força do coletivo e do protesto público a sua forma de luta. Mas, para o autor, não devemos desprezar as primeiras enquanto formas de resistência nem enquanto ação política, já que estas podem efetivamente vir a ter um efeito avassalador sobre o sistema de controlo, nem que seja a longo prazo. Esta resistência 'invisível' pode paulatinamente ir corroendo os mecanismos de controlo a partir de dentro, tornando o sistema disfuncional e improdutivo, o que pode 
conduzir a reformas e forçadas e alterações no modelo de produção e de controlo. Além disso, além destas práticas serem tendencialmente individuais, elas dependem de um conhecimento tácito comunitário e coletivo, que atua quase como um pacto de silêncio entre todos aqueles que podem vir a utilizá-las de forma autónoma.

A história dos Anonymous, grosso modo, ilustra quase a passagem de um modelo de resistência quotidiana e individual (embora inserida numa lógica coletiva, que era o funcionamento do 4chan) para um tipo de intervenção mais conotado com o ativismo político e social, que procura dar mais visibilidade a si mesmo. As formas de resistência apolíticas ou aparentemente descomprometidas socialmente podem, no entanto, contribuir para o desenvolvimento de certos tipos de ativismo, como acabou por acontecer neste caso. Não é pois a priori que devemos considerar uma atitude política ou não política, ativista ou não ativista. Há muitas formas de resistência aos comportamentos autoritários, repressivos e hegemónicos e, frequentemente, esses manifestam-se na própria vida pessoal e privada de cada indivíduo. Talvez seja então importante recordar, neste ponto, a famosa máxima da feminista Carol Hanish (1969) de que "o pessoal é político". Porque se, nas redes sociais, o anonimato pode ser uma forma de luta e de resistência, o seu oposto, que é a personalização das questões públicas, também assume um caráter emergente que importa observar.

\section{Personalização vs Anonimato}

Como já foi dito antes, as estratégias de manutenção da privacidade fornecidas pelo Facebook e pelo 4chan são substancialmente diferentes. Enquanto no segundo essa garantia deriva do anonimato, já no primeiro ela depende das opções e definições de cada utilizador, mesmo que nunca possa ser plenamente cumprida. Essa diferença deriva diretamente da própria 'natureza' e dos propósitos de cada uma destas redes sociais. Enquanto o 4chan é essencialmente uma plataforma de partilha de conteúdos, o Facebook, embora também acumule essa função, é acima de tudo um mecanismo de extensão do self e das suas relações sociais no ciberespaço. No entanto, isso não torna uma das redes mais ou menos política do que a outra. De formas diferentes, ambas podem servir para debater questões políticas e, mais do que isso, para questionar ou ajudar a re-significar o próprio conceito de política. Talvez se possa considerar o Facebook mais propício para um tipo de ativismo que procura a visibilidade e a mobilização social. Mas da mesma forma que, como vimos, o 4chan pôde servir esse propósito, também o Facebook pode ser palco para outro tipo de intervenções políticas.

Há inúmeros grupos ativistas que têm atualmente uma página no Facebook onde revelam as suas atividades. É indiscutível que nos dias de hoje o Facebook é uma importante plataforma para garantir a visibilidade social de diversas instituições. Essa será uma das funções e objetivos de possuir uma página nesta rede social: promover uma instituição ou grupo, 
apresenta-los publicamente e revelar as suas ações e iniciativas. Isto é válido para qualquer instituição e não apenas para grupos ditos ativistas. Mas, além desta autopromoção de entidades particulares, o Facebook serve também para projetar ideias, conceitos, posicionamentos ideológicos ou mesmo para divulgar informações relativas a certos temas que habitualmente são ignorados pelos media mainstream. Todas estas estratégias servem para configurar um perfil público de instituições, grupos e movimentos. São representações de si mesmo, da sua identidade, daquilo que defendem e daquilo que os mobiliza. Ou seja, existe aqui um propósito identitário, de assumir um determinado papel, uma determinada conduta e de agir em nome de determinadas causas, usando essa identidade assim construída.

Porém, tendo em conta que esta plataforma tecnológica oferece as mesmas ferramentas a todos os utilizadores, estas estratégias são também utilizadas individualmente por pessoas particulares para se apresentarem publicamente. $\mathrm{E}$, a partir da identidade que cada indivíduo projeta de si mesmo, novos coletivos podem daí estabelecer-se, por concordância ou proximidade ideológica e identitária. As redes pessoais dos utilizadores do Facebook assentam, na maioria dos casos, nas suas redes de socialização prévias e alheias ao ciberespaço. No entanto, os já analisados mecanismos de partilha, comentário e like podem contribuir para a expansão (ou redução) dessas redes. Uma forma de reforçar e ampliar as identidades são as conexões que se estabelecem, através desses mecanismos, com outras pessoas que partilham de certos elementos identitários e/ ou ideológicos e demonstram concordância ou aprovação. Isso pode conduzir inclusivamente a que se adicione essa pessoa (que pode ser um desconhecido) à rede de amigos. Em sentido inverso, comentários nocivos ou que sejam considerados ofensivos ou inapropriados na página pessoal de alguém, podem levar a um processo de bloqueio, apagamento da mensagem ou mesmo de "desamigamento" dessa pessoa, que fica assim impedida de voltar a intervir naquele espaço 'privado'. Ou seja, as identidades pessoais são aqui também negociadas e construídas coletivamente.

Os coletivos que se formam no Facebook em torno de uma ideia ou de uma causa podem, pelo funcionamento em rede, atingir proporções francamente notáveis. É, por isso, um meio que pode funcionar como um grande catalisador da ação política em larga escala. Exemplo disso foi o conjunto de manifestações ocorridas em Portugal em março de 2011 e que ficou conhecido como o protesto da "Geração à Rasca". A iniciativa partiu de um grupo de amigos e conhecidos que, através do Facebook criaram um evento público, convocando uma manifestação nas ruas e sintetizando num manifesto os seus intentos e objetivos, onde se apresentavam como um movimento "apartidário, laico e pacífico" que reivindicava melhores condições de trabalho e o fim da precariedade. Estima-se que cerca de 400 mil pessoas tenham saído à rua no dia 12 de março, sendo que a maioria reuniu-se na cidade de Lisboa, mas o protesto espalhou-se por diversas cidades do país. Estas foram, provavelmente, as 
maiores manifestações públicas não vinculadas a partidos no pós-25 de abril em Portugal. E revelaram como as redes sociais cibernéticas, à semelhante do que também já acontecera noutros países, podem contribuir decisivamente para fomentar formas tradicionais de manifestação pública, política e ideológica.

No entanto, além dessas formas 'clássicas' de protesto, penso que o Facebook pode alimentar outro tipo de contrapoder e de resistência, não tanto conotado com o 'ativismo'. Poder-Ihe-íamos chamar uma resistência existencial e identitária que se situa ao nível do indivíduo e que passa pela afirmação do seu lugar no mundo. Hannah Arendt (1989), em Origens do Totalitarismo, considera que uma das tendências e causas de uma sociedade totalitária é a diluição do indivíduo numa massa amorfa de gente que, perdendo a sua identidade individual, acaba por aceitar fundirse num todo que, embora questionável, acaba por apresentar-se como coerente. O Facebook oferece uma possibilidade de uma recriação do self e da afirmação do mesmo perante um coletivo, legitimado pelas conexões que consegue estabelecer. Essa identidade pode revestir-se de várias roupagens e construir-se através de diversas estratégias. Pode ser feita com fotos, com texto, com aspetos da rotina diária, pensamentos soltos, referências à família ou amigos, a atividades em que se envolveu, excertos de livros, músicas ou imagens de filmes. E nesse processo de edificação identitária, podem cruzar-se ideias políticas com ideias apolíticas, ações ativistas com não ativistas.

O meu argumento é que o próprio processo de afirmação de uma identidade pessoal no Facebook é, em si mesmo, político. É uma afirmação de um lugar existencial, de um modo de estar e de ser, de um posicionamento face ao mundo. É um processo de resistência ao anonimato e à impessoalidade, pela afirmação de uma personalidade individual que existe publicamente e interage coletivamente. Mas é precisamente pela conjugação desses dois fatores - personalização e interação - que o Facebook apresenta um potencial de "policiamento cívico" muito superior ao 4chan, onde o mesmo é praticamente nulo. Cada usuário tenta assumir a sua própria identidade, mas está também permanentemente consciente de que aquilo que ele mostra vai ser visto e eventualmente avaliado por outras pessoas. Pode inibir-se de dizer certas coisas ou de comentar certos assuntos por recear reações negativas. Ou, pior ainda, dizer algo tão politicamente incorreto que isso pode sair do seu controlo, espalhar por outras redes e tornar-se viral. Talvez nem todos os utilizadores tenham total consciência dessa possibilidade, até por terem redes pequenas e limitadas. Mas é sensato acreditar que a larga maioria estará pelo menos alerta para a possibilidade, mesmo que remota, de isso poder acontecer.

Claro que existe também quem crie perfis 'falsos' no Facebook, ou seja, não personalizados, com o objetivo de "trollar", de jogar, de vender, de ter acesso a outros sites ou para realizar qualquer outra atividade na qual a pessoa prefira não ser identificada. Mas isso é um outro fenómeno que daria um artigo por si só. Há também casos em que o anonimato é 
usado como uma estratégia de ativismo. Por exemplo, a página "Truques da Imprensa Portuguesa", que se dedica a estabelecer uma rigorosa vigilância ao jornalismo que se faz em Portugal, tem sido comentada por isso. A página tornou-se popular e é seguida por muitos jornalistas profissionais, que podem sempre ver o seu trabalho ali discutido e criticado. Também por isso, a página já despertou o interesse da imprensa oficial e já se publicaram artigos em jornais de referência sobre ela. No entanto, uma das críticas frequentes à mesma é a de que os seus administradores "não dão a cara", ao contrário dos "verdadeiros" jornalistas. Os próprios administradores, na sua página, já por diversas vezes comentaram e rebateram essa crítica, dizendo que isso é uma forma de se protegerem, pois eles, não sendo jornalistas, têm carreiras próprias e não querem sofrer represálias pelas intervenções que vão fazendo, que podem sempre ferir algumas suscetibilidades. Este é o outro lado da personalização e do assumir das identidades: de uma certa forma, acaba por ser mais restritivo e socialmente "perigoso". O anonimato pode de facto transformar as pessoas numa massa amorfa e invisibilizá-las, mas acaba também por protege-las melhor.

\section{Politicamente correto vs Liberdade de expressão}

A questão do anonimato e da sua legitimidade é complexa e levanta inúmeros desafios éticos e implicações morais. Se, por um lado, ele pode ser a garantia de privacidade, liberdade, segurança e de uma forma de intervenção política típica dos que estão desprovidos de poder, por outro lado ele desprende os indivíduos do seu "contrato social", deixando-os numa situação de total desresponsabilização cívica e deontológica, em que tudo passa a ser potencialmente permitido. Nesta situação, restará a consciência e a ética individual de cada pessoa para controlar a sua forma de interação pública. A liberdade total de agir, seja pelo lulz, por algum tipo de ativismo ou por qualquer outra razão, poderá ser sempre usada de uma forma ética e responsável, respeitando os espaços existenciais de outros, ou poderá assumir um caráter diametralmente oposto, fazendo do desprezo pelos valores cívicos a sua norma. Os trolls, tendencialmente, situam-se no segundo caso. E com a sua ação arrastam outros consigo. $\mathrm{Na}$ realidade, é verdadeiramente impossível 'vencer' uma discussão com um troll: o simples facto de haver uma discussão já é a sua vitória, uma vez que o seu propósito é apenas o de criar instabilidade, irritar e provocar outras pessoas e não o de enveredar em qualquer tipo de debate racional. Ou seja, a única forma de retirar poder a um troll é ignorando-o ou, por qualquer meio, silenciando-o e impedindo-o de difundir o seu manancial de raiva.

Impedir alguém de falar ou de expor as suas ideias num espaço público pode ser considerado um ato de censura. E qualquer ato de censura pode ser considerado uma restrição intolerável à liberdade de expressão, numa sociedade que tem nessa premissa um dos seus componentes ideológicos fundamentais. No entanto, consideremos o caso 
das páginas pessoais (ou mesmo institucionais) no Facebook. Como já foi dito, apesar de elas constituírem espaços públicos de uma abrangência imprevisível, são também espaços privados na medida em que o seu administrador pode escolher o que ali é publicado, quem pode publicá-lo e quem pode vê-lo. Nesse sentido, quando alguém apaga um comentário ou elimina alguém da sua rede por considerar certas ideias impróprias ou inadequadas ao seu espaço de gestão pessoal, poderemos considera-lo censura, mas será difícil não aceitar a legitimidade de tal atitude. Sendo um espaço simultaneamente público e privado, o que lá é exposto afeta também a imagem e a identidade que o indivíduo, o grupo ou a instituição em causa pretende transmitir de si mesmo. E o sentimento de que aquele espaço é, de certa forma, privado, justifica que alguém possa sentir a sua propriedade invadida por 'agressores' de algum tipo. Já no 4chan, em particular no /b/, este tipo de regulação censória torna-se impossível.

A questão que aqui se levanta é se a liberdade de expressão deve ser um valor absoluto e inquestionável per se, independentemente das consequências e da forma como é usada. Nos últimos meses, a importância do "politicamente correto" tem voltado em força à agenda pública, redes sociais incluídas, muito devido à ascensão de movimentos "populistas" conotados com a extrema-direita, tanto na Europa como nos Estados Unidos da América. A vitória de Donald Trump nas eleições presidenciais estadunidenses foi talvez o principal catalisador para que esta discussão voltasse à ordem do dia. Historicamente, o politicamente correto foi uma prática que cresceu e se difundiu nos EUA, espalhando-se depois por todo o Ocidente, com maior ou menor aceitação. Mas sobretudo a nível dos media e do discurso político oficial, esta tendência foi-se generalizando $\mathrm{e}$ instituindo paulatinamente. $\mathrm{O}$ propósito do politicamente correto era o de promover um tipo de comunicação mais inclusivo, de forma a romper algumas das representações normativas e depreciativas de grupos socialmente desfavorecidos, como as mulheres, as minorias étnicas ou os homossexuais. Trump alicerçou a sua campanha num discurso que não só desafiava como ostensivamente quebrava os fundamentos do politicamente correto. Também por isso, a sua vitória era tida como quase impossível ou altamente improvável. Mas a verdade é que ele acabou por vencer.

Há várias ilações ou pelo menos conjeturas que poderemos retirar desta improvável vitória. Uma delas é que talvez uma grande percentagem da população tenha deixado de acreditar no modelo políticoeconómico dominante e, consequentemente, nos discursos habituais, repetitivos e politicamente corretos dos seus representantes. 0 aparecimento de uma figura marcadamente antagonista deste modelo (pelo menos a nível discursivo), mesmo que inicialmente acolhida com desdém, escárnio e incredulidade, acabou por atrair, aparentemente, largas hostes de votantes insatisfeitos. O politicamente correto não será, por si só, a causa da insatisfação destas populações, mas surge associado a todo um modelo de gestão política e social que dá sinais de colapso e provoca descrença. Além disso, a quebra do politicamente correto 'liberta' 
as ideologias de grupos extremistas que viviam mais ou menos camuflados e eram genericamente olhados com desconfiança, como os grupos de extrema-direita assumidamente racistas, machistas e homofóbicos. Ironicamente, num período histórico em que se tornaram minoritários, os simpatizantes destas ideologias tornaram-se publicamente defensores da "liberdade de expressão", acusando o politicamente correto de ser uma nova forma de censura e normatividade. Apesar de defenderem ideologias opressivas para grupos minoritários, passaram a adotar elementos discursivos dos oprimidos.

A liberdade de expressão é seguramente uma conquista social significativa face aos regimes totalitários e marcadamente opressivos. No entanto, uma das suas consequências ou um dos seus maiores desafios é precisamente a extensão desse direito a grupos ideológicos que defendem a restrição dessa mesma liberdade de expressão. Em redes sociais como o Facebook, a liberdade de expressão vive quase em permanente conflito com o politicamente correto, precisamente porque há lugar para disputas e um jogo agonístico entre identidades divergentes. Há formas de silenciar ou ignorar opositores, assim como é possível utilizar os seus próprios discursos como arma de arremesso contra eles mesmo. Por exemplo, quando se partilha a publicação de alguém para outras redes, com comentários críticos que visam re-significar ou subverter aquele conteúdo, deslegitimando e descredibilizando assim o seu autor, publicamente. A liberdade de expressão é também a possibilidade de conflito e, numa rede personalizada como o Facebook, esse conflito coloca em confronto identidades e ideologias mais ou menos definidas. Porém, no universo do trolling e na ausência deste policiamento cívico, como é o caso do 4chan, a liberdade de expressão pode conduzir a caminhos imprevisíveis, nomeadamente a total destruição do que é (ou deve ser) politicamente correto.

A defesa da total liberdade de expressão enquanto valor absoluto merece sem dúvida ser debatida. Mas, independentemente do posicionamento ideológico de cada um sobre o tema, o que é uma realidade é que quem frequenta as redes sociais (não exclusivamente estas duas de que trata o texto) tem de deparar-se regularmente com estas questões. Até onde vai a minha liberdade de expressão? Devo dizer tudo que penso ou evitar ferir suscetibilidades? O que fazer na presença de um troll? Devo ocultar a minha identidade ou torna-la pública quando entro num determinado site ou fórum? Como reagirão os coletivos que me seguem àquilo que pretendo publicar? Na verdade, todas estas questões podem também colocar-se no processo de socialização fora do mundo cibernético. Tal como fora dele há pessoas mais expansivas e outras mais reservadas, algumas com posicionamentos políticos mais vincados e outras mais focadas noutras áreas de interesse. Porém, o que torna diferente a comunicação nas redes sociais da internet é a projecção exponencial do que é dito tanto no espaço como no tempo. Aquilo que é publicado numa rede social pode atingir uma enorme diversidade de públicos e pode ser conservado indefinidamente no tempo. $E$, nesse 
processo, as estratégias de preservação da privacidade e da identidade face ao policiamento cívico adquirem particular relevância e tornam-se perfeitamente justificáveis, embora nem toda a gente as siga.

\section{Verdade vs Pós-verdade}

Outro dos riscos inerentes à utilização das redes sociais é a possibilidade de alguém descontextualizar ou reinterpretar uma determinada publicação de forma abusiva e mal-intencionada. Esse é um outro aspeto que poderá conduzir a um processo de autocensura ou a um maior cuidado com o tipo de discurso e de informação que se publica. A ironia, por exemplo, nem sempre é bem digerida pelas redes sociais. $E$, embora alguém possa estar confiante que, dentro da sua rede de amigos e seguidores, esse comentário será entendido como cáustico e mordaz (até por relação com o restante perfil), no caso do mesmo ser partilhado num outra página e, como tal, descontextualizado da sua lógica original, pode vir a ser reinterpretado de forma totalmente diferente. Por exemplo, ainda recentemente ocorreu um caso mediático que ilustra bem esta situação, com uma página de Facebook intitulada "As minhas insónias em carvão". Este é um espaço assumidamente satírico e humorístico, cuja principal estratégia comunicativa passa pela criação de "memes" falso, criados a partir da distorção de imagens com recurso ao Photoshop, com vista a subverter as mensagens originais. Num desses casos, o autor publicou uma imagem de adeptos do Sporting com uma tarja onde a mensagem original tinha sido alterado, sugerindo que eles agora torceriam pelo Porto. Alguém pegou nessa imagem e difundiu por outras redes, como se fosse uma imagem real. Como é comum no futebol, isso gerou uma onde de indignação e revolta entre adeptos de outros clubes (nomeadamente do Benfica) que usaram isso para atacar os seus rivais. A imagem chegou mesmo a ser utilizada num programa televisivo sobre futebol, como sendo real. O autor e gestor da página publicou sobre isso o seguinte comentário:

Aparentemente um tal de [nome do utilizador] acabou de mostrar a minha montagem do "Sporting quer o Porto campeão" na televisão, com o intuito de incendiar os adeptos. Uma coisa sou eu aqui, onde sabem que é tudo montagem, outra é tirar uma imagem minha fora do contexto e usá-la para atiçar o fogo.

Estou cheio de vergonha por ter ajudado este tipo de programa de [uso de calão] a "meter carvão" (apesar do nome da página!).

[nome do utilizador], és tudo o que está errado no futebol em Portugal.

Vou apagar o post, apesar de ter plena consciência que já fugiu das minhas mãos. 
Este é um exemplo bem revelador de como aquilo que se publica numa rede social pode sair totalmente do controlo de quem a publicou. 0 autor revela total consciência disso mesmo na última frase. E este aspeto de uma publicação poder "fugir das mãos" do seu criador é uma das características das redes sociais que pode provocar um clima permanente de incerteza sobre aquilo que se vê e que se lê. Hoje em dia, vulgarizouse o conceito de "pós-verdade" para nos referirmos a este fenómeno. Também aqui, a eleição de Donald Trump teve alguma influência na difusão do conceito, pela sua assertiva rejeição de postulados científicos amplamente aceites, como o caso das alterações climáticas, usando estratégias argumentativas como "eu acredito que não é assim". A pósverdade é, afinal, um universo comunicacional público em que deixa de haver uma forma de validar ou comprovar aquilo que é efetivamente real e fidedigno, passando a existir sobretudo um regime de crença e de opinião puramente especulativa, que não pode ser validado senão por simpatia ideológica ou pessoal. Em suma, é a aniquilação dos valores do Iluminismo e do pensamento científico, a destruição de um sistema referencial de separação entre o que é verdadeiro ou falso. De uma certa forma, é quase a aplicação prática daquilo que os pós-modernos teorizavam há duas gerações atrás, mas agora usado com propósitos de mobilização social e política e não de emancipação do pensamento divergente e defesa do relativismo cultural.

Será importante perceber de que formas os mecanismos funcionais das redes sociais, particularmente do Facebook (pois será entendido como mais "sério" e mais fidedigno que o 4chan), podem contribuir para o alastrar deste fenómeno da pós-verdade. O exemplo citado é um bom ponto de partida, pois revela algumas das possibilidades comunicacionais permitidas pelas novas tecnologias, nomeadamente a manipulação de imagens de uma forma relativamente fácil e acessível. É certo que a hipótese de manipular imagens não é exatamente uma novidade, pois isso já acontecia tanto na imprensa como na televisão - nesses casos, teria de ser o código deontológico dos jornalistas a evitar que tal acontecesse. No entanto, o que muda com as novas tecnologias é que essa possibilidade fica ao acesso de qualquer usuário de computadores e redes sociais, bastando para isso alguns conhecimentos rudimentares de algum software específico. É certo que isso pode ser feito apenas com propósitos recreativos ou humorísticos, como neste caso específico. Mas o exemplo também demonstra como isso pode acabar por tornar-se numa coisa totalmente diferente do propósito original.

Mas não são apenas publicações humorísticas e satíricas que podem tornar-se virais e acabar por ser re-significadas. Nas redes sociais proliferam também as partilhas das chamadas "fake news", notícias falsas, que têm origem em diversas fontes, mas sobretudo em sites que se dedicam exclusivamente a isso, tanto com propósitos meramente humorísticos como com objetivos económicos, nomeadamente para aumentar o valor dos espaços publicitários dessas páginas. Essas notícias têm geralmente títulos sensacionalistas que visam captar as atenções do 
máximo de internautas possível, mesmo que os conteúdos, por vezes, estejam até desligados dos títulos. O objetivo é, acima de tudo, provocar o "clickbait", ou seja, o simples ato de clicar na ligação e abrir aquela página, ampliando assim as receitas da mesma. Nada disto é propriamente nocivo em si mesmo, já que, de várias formas, é fácil perceber que um site de fake news não passa disso mesmo, de notícias falsas. No entanto, no seu cruzamento com as redes sociais e através do mecanismo de partilha, tantas vezes pode ser uma notícia reproduzida e republicada que, a determinado ponto, perde-se a fonte original e a única coisa que passa é o conteúdo fictício da mesma, particularmente o seu título sensacionalista.

Este fenómeno acaba por tornar-se muito menos inofensivo do que parece. Porque as notícias falsas podem contaminar muitas redes de informação, mesmo de sites noticiosos oficiais. Já aconteceu órgãos respeitados da imprensa nacional e internacional divulgarem informações falsas como sendo verdadeiras, às vezes mesmo de forma inconsciente. A página dos "Truques da Imprensa Portuguesa" já por mais que uma vez denunciou situações dessas, mesmo que horas depois as notícias acabassem por ser retiradas. Mas esse perigo de contágio é real. E mesmo que uma notícia seja denunciada como falsa num determinado momento, nada impede que, meses depois, quando essa informação já desapareceu da memória coletiva, ela não volte a ser apresentada como real, pela já falada característica de preservação no tempo das publicações no espaço cibernético. O que acaba por ser mais desafiante nesta situação é a fusão de notícias verdadeiras e falsas nas mesmas plataformas. Porque, se nos sites de fake news é fácil perceber que tudo é mentira, quando no feed do Facebook as notícias falsas se misturam com as verdadeiras, torna-se bem mais complicado separá-las e destrinçar entre o que é ou não real. Até porque nem sempre os utilizadores estão dispostos a ir verificar a fonte da informação e avaliar o seu grau de fiabilidade.

\section{Conclusão}

As redes sociais tornam-se, cada vez mais, um modelo paradigmático das relações sociais no mundo contemporâneo. Elas reproduzem, a vários níveis, um tipo de interações essencialmente urbano, onde cada pessoa tem uma certa dose de liberdade e de autonomia para escolher em que coletivos pretende integrar-se. Estes coletivos inscrevem-se em redes sociotécnicas, que dependem não só das ações dos seus utilizadores como das possibilidades de ações que as plataformas tecnológicas Ihes oferecem. Por isso, é importante perceber que cada rede social tem características próprias e permite fazer coisas diferentes de outras: os casos do Facebook e do 4chan são exemplos de plataformas bem distintas e que possibilitam diferentes tipos de relações sociais. O processo de socialização através destes coletivos sociotécnicos contribui então para a necessidade de repensar e redefinir alguns conceitos mais ou menos cristalizados no senso comum, como as noções 
de público e privado, de resistência e ativismo, de intervenção política ou de afirmação de uma identidade particular. São também um palco onde se desenvolvem novos conceitos, como "pós-verdade" e onde os limites da liberdade de expressão são desafiados, pelo surgimento de espaços existenciais onde as regras de socialização ditas normais podem ser permeáveis e expansíveis.

No entanto, estas redes não deixam de atuar como mecanismos de controlo social, onde podem surgir novas moralidades e desafios. Sobretudo em plataformas onde a personalização das identidades é um aspeto dominante, como no caso do Facebook, há vários mecanismos que contribuem para um contínuo "policiamento cívico", em que os próprios utilizadores se vigiam e se disputam mutuamente em nome do politicamente correto ou moralmente aceitável. Estes conceitos não são estanques nem geram necessariamente concordância. Na prática quotidiana da socialização nas redes sociotécnicas, estes conceitos são performatizados e negociados num jogo agonístico contínuo. Acima de tudo, estas redes constituem-se como palcos de ação identitária e ideológica, quer através da personalização, quer através do anonimato, quer através de um ativismo explícito e assumido, quer através da simples afirmação de um lugar existencial. A existência enquanto resistência é uma das ideias que as redes sociais permitem materializar. Uma existência coletiva, relacional, disputada, simultaneamente pública e privada, pessoal e política. De certa forma, a possibilidade de um ativismo individual, mas que apenas poderá resultar da interação coletiva.

\section{Referências:}

ARENDT, H. As origens do totalitarismo. Raposo; São Paulo: Companhia das Letras, 1989.

ARRUDA, J. A Fusão dos espaços públicos e privados no novo paradigma comunicacional. Sociologia On Line, n. 11, 2016. Disponível em:

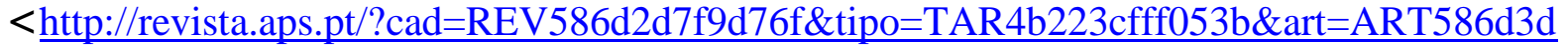
b7108b6 >. Acesso em: 10 abril 2017.

COLEMAN, G. As muitas faces dos anonymous. Lisboa: Relógio de Água, 2016.

HANISCH, Carol. The personal is political. 1969. Disponível em: <http://www.carolhanisch.org/CHwritings/PIP.html>. Acesso em: 11 abril 2017.

SCOTT, J. C. Everyday forms of resistance. Copenhagen Papers, Copenhaga, n. 4, p. 33-62, 1989. 